\title{
CHOREOGRAPHICAL ARTS AS A MEAN OF INTEGRATION OF STUDENT YOUTH TO EUROPEAN SPACE
}

\author{
Lilia Savchyn, \\ honoured worker of arts of Ukraine, doctor of historical sciences, associate professor, \\ professor of department of choreography, Rivne state humanitarian university, \\ Alla Samohvalova, \\ senior teacher of department of choreography, Rivne state humanitarian university
}

DOI: https://doi.org/10.31435/rsglobal_ws/30042020/7027

\section{ARTICLE INFO}

Received: 13 February 2020

Accepted: 08 April 2020

Published: 30 April 2020

\section{KEYWORDS}

choreography, art, integration, student youth, Eurospace.

\begin{abstract}
The article deals with the issues of student youth activity towards Eurospace. The actualization of choreographic art at the present stage of cultural formation is substantiated. Choreographic art is analyzed as a means of integration into Eurospace. Interacting with the contemporary demands and needs of society, the art of dance influences social relations, economic order, political, ethnic and national relations. It is emphasized that choreographic art is a socially significant value and is a feeling-filled aesthetic reproduction of knowledge, skills and competences.
\end{abstract}

Citation: Lilia Savchyn, Alla Samohvalova. (2020) Choreographical Arts as a Mean of Integration of Student Youth to European Space. World Science. 4(56), Vol.2. doi: 10.31435/rsglobal_ws/30042020/7027

Copyright: (C) 2020 Lilia Savchyn, Alla Samohvalova. This is an open-access article distributed under the terms of the Creative Commons Attribution License (CC BY). The use, distribution or reproduction in other forums is permitted, provided the original author(s) or licensor are credited and that the original publication in this journal is cited, in accordance with accepted academic practice. No use, distribution or reproduction is permitted which does not comply with these terms.

The attention to the Euro-space of the early 21 st century is first and foremost related to artistic trends in culture and education. That is why the student youth of Ukraine is now confidently paving the way for the future and mastering the European space in various ways and means.

Particular interest in choreographic art as a means of integration into the European space of the modern scientific community is due to the fact that the solution of issues of culture, art, education, economy, politics are key in the general problems of the world view. The contemporary Euro-spatial nature of the problematic issue is related to the global processes that are currently taking place in societies. The rapid pace of development of art - biennials, festivals, forums, exhibitions, competitions, concerts testify to the growing interest of young people in the dynamic tendencies in the problems of contemporary art. It is impossible to delineate the boundaries of styles, types and genres in art, including choreographic. The vividness of such a picture clearly testifies to the relevance of the study of choreographic art as a means of integrating student youth into European space.

The basic concepts of the study are the integration of student youth into the European space. Choreographic art is regarded as a leading means of youth entry into the art of European space.

The purpose of the article is to analyze the peculiarities of integration of student youth into the European space, to distinguish conceptual approaches and scientific ideas to solving problems on the way of youth entering the world of European space.

The subject of the study is social, cultural, educational, artistic factors as a means against which the integration process of student youth into the Euro-Space countries takes place. Choreographic art as an independent phenomenon of the modern spatial model.

Choreography is a kind of catalyst of the modern world, its visual perception needs a new understanding, deep psychology, clear principles of artistic ethics, the basis of which is the affinity of spirituality and humanistic values, which, interacting, dynamically interact in the European space. 
The problem of the study of art in its multifaceted manifestation (and integration, in particular - ed.) (Not something fundamentally new to science) - has been repeatedly considered by well-known thinkers of the past, and its importance is reinforced by life itself.

The concept of space was first discovered in O. Shpengler's work "The West of Europe" (1918). The author clearly outlines the importance of space not only for individual perception, but also for culture in general and for all arts that exist within a particular culture. Space is a symbol of a culture from which it is possible to distinguish the language of its forms, which is different from another culture. Spengler's leading characteristic of space is its depth.

Space is an integral characteristic of a work of art [6].

Heidegger M. distinguishes the types of space: the space of science by connecting with technology, the space of daily behavior and communication, the space of art. Artistic space as a result of the interaction of art and space must be understood not as a reproduction or subjugation of physical and technical space, but based on the understanding of place and sphere, or space itself. Artistic space is the means by which a work of art is imbued [2]. It follows that the unity of space and space creates a fertile ground for integration into (in our study ed.) Eurospace.

S. Vygotskii (psychological context), O. Semashko (sociological aspect), L. Kogan (educational perspective), S. Bezklubenko (social nature of art), O. Rudnitska (art pedagogy), $\mathrm{N}$. Yarantseva devoted their attention to the problems of art. (art as an object of social functioning).

Based on scientific and artistic research on the concept of M. Bakhtin, M. Roerich, V. Kozhinov, N. Miropolska determines the place of a person in culture and art. She notes that art is a special world of thoughts, impulses and feelings embodied in the movement of the brush, rhythms of poetry, gestures of the actor, film footage... Art is the spiritual heritage of humanity [1, p.7].

Rudnitska O. emphasized that worldview is the most important function of art, its dominant, from which all other functions derive: educational, social-organizational, communicative, axiological [3, p.51].

According to O. Rudnitska, art is a socially significant value and is a sense-filled aesthetic reproduction of morality. Depth, strength and intensity of emotional experiences caused by art is spreading to all spheres of vital activity, exacerbating the emotional sensitivity of the individual to life events, giving it a distinct emotional color to the process of teaching students of artistic specialties, and creating additional spiritual conditions. 42].

Features of educational potential of choreography were investigated by (P.I. Koval, A.S. Tarakanova, A.V. Fomin, I.V. Khizhnyak); the use of the traditions of folk choreography are analyzed in the works of (T.I. Badmayev, K.V. Vasilenko, K.A. Gevorgian, A.S. Zoltaeva, A.I. Shevchuk and others).

There are a number of scientific and pedagogical studies in which choreography is considered as one of the auxiliary means of physical, mental and moral education of the person (N.S. Vlasova, V.M. Griner, L.M. Dzerzhinska, M.S. Koltsova, F.A. Ratz, A.V. Fomin and others).

All this confirms the multifunctional role of choreographic art, which we consider as a means of integrating student youth into the European space.

Choreographic art functions in the society according to certain specific laws and, rooted in the tradition of previous generations, synthesizes the positive experience of the past. It reflects the state of moral health, the level of economic and political freedoms, and, accordingly, may characterize its spiritual potential.

Interacting with the contemporary demands and needs of society, the art of dance influences social relations, economic order, political, ethnic and national relations. Art makes adjustments to the spiritual composition of society, serves as a prerequisite for the stabilization of all sides of social life, and thus provides an appropriate balance of historical and cultural formation.

Choreographic art, as a treasure trove of collective experience over thousands of years, has long been considered a traditional acquisition of humanity and, by and large, is the ultimate outcome of the lives of individuals, creative teams of all levels.

Thus, the assimilation of art and its integration into the European space is an important guarantee of the development and interaction of human civilization. Therefore, the study, assimilation, protection against distortions, multiplication and transmission to the next generations, then, the integration of the major achievements of art is a matter of honor and responsibility.

Historically, each epoch builds its own characteristic features of art, and, in some places, one species prevails over another.

The beginning of the 21st century is marked by a rapid vector of the development of art, choreographic, in particular. The growing interest of young people in the art of dance gives rise to a 
legitimate desire to make the most of the reserves of plastic body language, demonstrating an interest in their own artistic worldview and acquired competences in the educational space.

After all, Euro-space requires not only fox-steps, but confident steps within the legal framework and specific institutions of socialization.

Thus, the Ministry of Education and Science of Ukraine actively publicized the concept of preparation of the Roadmap for Integration of Ukraine into the European Research Area (ERA-UA), which should be implemented under 6 priorities: effective national research systems, optimal transnational cooperation and competition, open labor market, gender equality in research, optimal exchange and transfer of scientific knowledge, as well as international cooperation.

Priority 6 (International Cooperation) recognizes the importance of effective international scientific cooperation to address pressing societal challenges, promote access to new growth markets, and increase the attractiveness of the European Research Area for ideas and investors worldwide.

Ukraine will take as an example the Austrian Roadmap, above all its structure and general principles. It should describe the current situation, goals to be achieved, what the indicators of change will be and so on. We should focus on concrete steps that bring us closer to European standards.

Careful reading of the materials of the Roadmap allows to motivate the concept of the influence of art on scientific research, political situation, economy, culture (ed.). Although there is no clear focus here, the line reads the active role of art, culture for socio-cultural cooperation and interaction in the Euro-space. The mission of this document is seen as the foundation - to enable society to share and effectively use art for harmonious development in the social, economic and personal dimensions of the Euro-space model.

Thus, D. de Rougemont emphasizes that "Europe is the birthplace of memory. It is even, in memory of the world, the place of the world where the oldest documents of the human race are stored and reproduced, and they do so not only in museums and libraries, but also in customs, traditions, language skills, in the vicinity of human relations "[5, with. 25]. This is why Europe is a role model. Preserving Europe's cultural color is the goal of constituting an integrative European educational space and its undeniable price. "True culture," says D. de Rougemont, "is not some kind of decoration, ordinary luxury, or a set of specialties that do not relate to the tradesman. It arises from the awareness of life, the constant need to deepen the meaning of life, to strengthen the power of man over things. It created the greatness of Europe" [5, p. 66]. Thus, according to the philosopher, the individual creation, integration and creation of culture is a consequence of the constant negotiation between a large number of trends. It is in such communication - the creative take-off of Europeans.

In view of this, integration (from the Latin integratio) can be considered as a process and the result of integrity and continuity. Integration is explored in the context of economics, social content and as a sphere of culture.

Integration is the foundation for Ukraine's further progress and the introduction of European standards for improving the quality of life in the country.

The integration of student youth into the European space should be elaborated within the framework of philosophy, cultural studies, pedagogy, psychology, art criticism. Art plays the role of a significant factor in the student environment. It directs young people to formulate value orientations, standards and a clear understanding of their own role in the Eurospace.

The integration of student youth into the European space should be elaborated within the framework of philosophy, cultural studies, pedagogy, psychology, art criticism. Art plays the role of a significant factor in the student environment. It directs young people to formulate value orientations, standards and a clear understanding of their own role in the Eurospace.

Student youth is the driving force of progress, the initiator of innovations, attitudes, ideas, whose value orientations dramatically influence the prospects of the development of society as a whole. It is a powerful intellectual potential of culture and economy, a potential elite of society. Student youth holds a leading position among the youth group, a dynamic part of society. Sensitively responding to any changes, it quickly captures the latest trends and integrates them at the level of Eurospace.

Choreographic art embodies an extremely powerful ability to develop a young person and to permeate all areas of life - from basic human needs to the greatest manifestations of human creativity.

The analysis of scientific sources and literature show that among the diverse variety of arts, choreographic art itself has a powerful force and ability to integrate.

We look at choreographic art in conjunction with students (higher education students) who are pursuing choreographer majors. 
The leading disciplines of the curriculum (classics, modern, ballroom, folk and folk-dance) reflect the educational level and spiritual state of society. Their competence should be considered as a source of education, mentality, mood, value needs. And yet, as a means of integration. Here, synthetically interconnected science, education, culture, which direct young people to research, education, upbringing and development, are the fundamental foundations that shape the values of youth in the Eurospace.

It is the art of choreography that plays the role of a significant factor in the cultural and educational sphere, shapes the orientation of students' interests and needs, encompassing the system of spiritual creativity and is a vector of dance integration in the European space.

Nowadays, an important task for all social institutions, including perhaps most of all higher education institutions, is to preserve art in the context of solving relevant and practically significant problems that are associated with the impact of art on the individual in the process of perception and study. and is a means of integration. As the art of choreography not only reflects the state of moral health of the society, the level of economic and political freedoms, but also characterizes its spiritual potential.

Choreographic art in modern society is a product of consumption and reproduction, which performs the functions of important elements - information, psychological, moral, material sphere of life in the context of the general culture.

Dialectically interacting in an educational environment, the art of choreography has the ability to reflect its state, level, potential. It is not only a factor in the education of the individual, it acts as one of the constituent elements of the combination of spiritual culture with education, but can also be a means of integration.

The art of choreography glorifies the individual in creativity, focusing in his work on humanistic values, public consciousness, truth and beauty. The art of choreography is the space where creativity or the act of creating something new is the center of human activity. The image of reality by any means has at all times promoted its comprehension and opened the secret deep ties of man and society. Art has always performed many functions, including integration.

Young teachers and students of the department of choreography at Rivne State Humanities University actively integrate the art of choreography into the European space by participating in various events and actions. For several years, they have been participating in international competitions for young ballet dancers «Dans Generation», Kyiv, Institute of Arts of Kyiv University. Borys Grinchenko (Ministry of Education and Science of Ukraine (№ 1 / 11-11923 from 05.11.2018), Ministry of Culture of Ukraine (№ 5905 / 9-1 / 13-18 from 05.12.2018).

Participating countries of the festival are Great Britain; The Kingdom of Spain; The Republic of Lithuania; The Republic of Estonia; The Republic of Finland; Republic of Belarus. Purpose of the event: to promote popularity of choreographic art of Ukraine, search for new forms of interaction in the framework of creative exchange with foreign partners, discuss topical issues of development of choreographic education in Ukraine and Europe, encourage dialogue between talented ballet dancers and dancers of Ukraine and the EU, search for new works talented performers.

The festival is held under the patronage of the Ministry of Education and Science of Ukraine, the Ministry of Culture of Ukraine. The main organizer is the department of choreography of the Kyiv University named after Boris Grinchenko.

In February-March 2018, Boris Grinchenko University of Kiev hosted the 1st Dance Generation Ballet Competition. In addition, a week-long workshop of teachers and students of the specialty "Choreography" of the Boris Grinchenko Institute of Arts and the University of de Montfort in Leicester (UK). The project was implemented within the framework of a creative exchange between the two educational institutions and was designated as a creative laboratory, which is in line with the new strategy for the development of choreographic education in Ukraine.

During this time, creative communication of students of these universities took place. The instructors conducted dance classes in classical, folk, contemporary dance and were able to get acquainted with the form and methods of teaching choreography from a senior teacher at De Montfort University in Leicester Joe Breslin during her classes and a lecture "Features of the educational process at De Montfort University in Leicester".

The result of the week's creative collaboration was the project (choreographic and musical performance) "The Art of Dialogue", which was presented on the stage of the Boris Grinchenko University of Kyiv.

The final stage was the Young Ballet Masters Competition Dance Generation, which was attended by over 200 Ukrainian participants, as well as students from a dance troupe at the University of Montfort in Leicester. 
At the discretion of the jury were presented the vivid works of young ballet masters of professional educational institutions and amateur artistic groups: De Montfort University in Leicester (United Kingdom), Boris Grinchenko Kiev University, Uman State Pedagogical University, Berdyansk Pedagogical University. M.P. Drahomanov, Rivne State Humanities University, University of Kyiv Boris Grinchenko University College, Kyiv State Choreographic College, Melitopol College of Culture, Uzhgorod College of Arts, Dnipropetrovsk College of Arts, Kharkiv College of Arts, "Velvet", Zhukovsky YSA №6, Contemporary Dance Ensemble "UNISON", Contemporary and Pop Dance Ensemble "GraciaDance", Dance Ensemble "Fairy", Dance Studio of Andrew Wild and Lilia Rebrik, Dance Studio "Renaissance Plus", Ensemble "Wings" of the choreography department Jazz and art school.

The competition was judged by a highly professional jury: senior dance instructor at De Montfort University in Leicester (UK), Joe Breslin; Chief Ballet Master of the Kyiv Municipal Academic Opera and Ballet Theater for Children and Youth Tatiana Borovyk; Honored Artist of Ukraine, Associate Professor of Choreography, Kyiv Grinchenko University, Chief Ballet Master of the Opera Studio of the National Music Academy of Ukraine. Tchaikovsky Vyacheslav Vitkovskii; choreographer, director of "Santha dance studio", teacher of contact improvisation at the Kiev National University of Culture and Arts Ruslan Baranov.

The following events took place in the format of the International Festival of Choreographic Arts: II International Dance Ballet Competition for Young Choreographers; All-Ukrainian scientific and practical conference (with international participation) of representatives of higher education institutions, professional dance groups, schools from partner countries (EU) and Ukraine "Dance Art and Choreographic Education: Experience, Development Trends and Prospects"; Series of master classes, creative collaborations, improvisation classes of the teachers of the choreography department of the Boris Grinchenko University of Arts and representatives of the participating countries, the final joint creative project [7].

Rivne State Humanitarian University was represented by students of the department of choreography. Graduates of category D grade were Kateryna Kosiuk and Iaroslav Cheveliuk; Nadia Panchuk and Dmytro Moskaliuk; Diana Osadcha and Alexander Borsuk; Sofia Artimko; Angelina Onishchuk. Head of Graduate Students Senior Lecturer was Alla Samokhvalova.

Participation in international competitions, olympiads, student exchange programs, educational projects (programs) (Work and Travel USA, Au-Pair, etc.) is presented by the International Cooperation Department of Choreography of the RSHU and the Department of Choreography of the Humanities and Economics Academy in Lodz, Poland. In May, in the framework of international cooperation, an Evening of Polish-Ukrainian Contemporary Choreography was held. Students demonstrated the art of modern dance under the tutelage of the choreography department professor Gorbachuk Roxana, Ph.D. Loban Tetiana.

A general cooperation agreement was concluded between the Rivne State Humanities University and the Lega City Sports and Recreation Center, Olecko, Poland. Therefore, in November 2019 the international festival competition "Lega Art Fest" was held. Co-organizers of the festivalcompetition were the teachers of the department Maneliuk E.V. and Maneliuk D.I. The founders of the festival are International Festival Group, NGO "Creative Workshop" Dialogue ", Lego City Sports and Recreation Center.

Students and teachers of the Department of Choreography of the RSHU participated in the International Choreographic Assembly, Natalia Skorulskain from Zhytomyr. For the participants and team leaders a master class on techniques of modern choreography and creation of choreographic performance "Voice of the Wind" was held.

In March 2019, teachers of the department were registered with an organization that is responsible for the preservation and development of all dance directions with the support of UNESCO.

In December 2019, the International Assembly of the Council of Dance took place in Paris. Senior teacher Larisa Markevich and teachers Olga Gordeieva, Ella Maneluk were its participants and had a meeting with the President of INTERNATIONAL DANCE COUNCIL, Mr. Alkis Raftis. A dialogue was held on the opening of the CID section in Rivne. Spain, Italy, Bali, Dominican Republic, Armenia, Finland, Iceland, Uzbekistan, Serbia, Macedonia, Japan, Kenya, Mexico, Moldova, India, Belgium, Bolivia, Belarus, Latvia, Malta and many other countries are members of this organization. There are 196 registered people in Ukraine. The organization is a platform for collaboration between professionals of various types and areas of choreographic art, an opportunity that allows you to collaborate with the world and create art projects of international level. 
Choreographic art cannot be imagined without numerous festivals and competitions. They take place on the world stage and present a wide range of styles and styles. The festival movement in the field of sports-ball choreography is the most popular and widespread. Dance festivals and competitions play social, cultural and artistic functions, as evidenced by scientific research. The history of the ballroom dance festival is almost ancient. However, he acquired a slim organization from the beginning of the twentieth century.

Ballroom dance today - from local distribution to Eurospace is extremely relevant. First of all, it is a system that includes a household, sports and stage component. Of the dance variety, ballroom choreography is the most common among the youth audience. Sport-ball choreography is a phenomenon focused on creating an artistic image in the show program, a focus on entertainment and refinement, demonstration of noble behavior, grace and justness.

Ballroom Dance Contest (from Latin concursus - coincidence, collision, meeting) is a creative competition of dancers (as well as choreographers) to identify the best creative achievements and plastic skills of participants. Competitions showcase new talents and improve skills, foster creative contacts and gain experience, enrich competencies and knowledge. Festivals and competitions have ample opportunity to promote and integrate choreographic art into the European space.

The Festival of Sports Ballroom Dance is an artistic event whose perspective develops according to the laws of the communicative and artistic spectacle, integrated and joint artistic activity aimed at a collective result. Such teamwork helps to improve the quality and effectiveness of the dance show itself and, accordingly, to understand the actual problems and their solution by means of choreographic art.

For sixteen consecutive years, an international forum, the Christmas Ball, has been taking place on the leading stages of Rivne. Leader of the project is teacher, honored art worker of Ukraine Roman Hrytseniuk. Sport-ball choreography is one of the leading places in dance projects. In December 2019, the program of the ball accumulated demonstration performances of bronze medalists of the European Championship of Latin American show among professionals. The program was opened by Alexander Pochtarenko and Anastasia Boguslavska. Athletes from all over Ukraine came to Rivne for the International Ballroom Dance Festival. The staff of the jury are well-known dancers from France, Italy, Romania, Greece, Moldova. Ukraine was represented by a panel of judges from Rivne, Lutsk, Lviv, Poltava, Odessa, Ternopil, Kharkiv, Chernivtsi, Cherkasy, Kiev.

The resource potential of choreographic art is unlimited. The direct participation of student youth in various cultural events is becoming an increasingly popular form of leisure. Particular attention in the choice of forms of involvement of the general public are festivals, competitions, concerts, which accumulate considerable social and economic stock, which make them commercially attractive. Also, the organization of art forums is of great importance for preserving the unified cultural space of the country and to reach a higher level - Eurospace, which will help the students to become aware of the harmonization of their lives.

Thus, choreographic art is now characterized by dynamic changes that take place in the process of continuous social, cultural, educational modernization.

It is the choreographic art that should be regarded as a source of knowledge, skills, competences and a means of integrating student youth into the Eurospace. Domestic and foreign art projects, competitions, festivals act as a tool in the integration process, since dance is an influential driving force of information, moral, educational, cultural life and has influence in socially significant processes of Eurospace.

Not only the creation of a high-quality, attractive, competitive product - dance, but also the integration of the national culture (dance) into the European space, which will promote the authority, recognition and economic growth of the country, is a significant direction.

\section{REFERENCES}

1. Miropolskaa N.E. Artistic culture of the world: European cultural region: Educ. manual. - K.: Higher school, 2001. - $191 \mathrm{p}$.

2. Soloviev V.S. Philosophy of Art and Literary Criticism / Introduction. article by R. Galtseva and I. Rodnyanska. - M.: Art, 1991.-701 p.

3. Rudnitska O.P. Basics of teaching art disciplines. - K., JSC "Express-advertisement", 1998.-183 p.

4. Rudnitska O.P.Pedagogy: general and artistic. - Teach. manual. - K., 2002. -270 p.

5. Rojmon D. Europe in the game. Chance of Europe. Open letter to Europeans. - Lviv: B. V., 1998. - 277 p.

6. Spengler O. Sunset of Europe. T.1. M., 1993. P. 416.

7. Materials of the program of the International Dance Choreographic Festival "Dance Generation" of the Boris Grinchenko University of Arts. 2019 